\title{
A SYNOPSIS OF ROMANIA'S SMART CITIES INNITIATIVES
}

\author{
Darie Gavrilut ${ }^{1}$, Diana Teodora Trip ${ }^{1}$, Carmen Florina Fagadar ${ }^{1}$, Daniel Badulescu ${ }^{2}$ \\ ${ }^{1}$ Doctoral School of Economics, Faculty of Economic Sciences, University of Oradea, \\ Oradea, Romania \\ ${ }^{2}$ Department of Economics and Business, Faculty of Economic Sciences, University of \\ Oradea, Oradea, Romania \\ darie.gavrilut@gmail.com \\ dianateodora.trip@gmail.com \\ carmen.fagadar@emanuel.ro \\ dbadulescu@uoradea.ro
}

\begin{abstract}
The term smart city is often associated with the desire for accelerated modernization of space and urban social interactions, especially based on Information and Communications Technologies. Smart cities are creative and sustainable areas that bring improvements on the quality of life, a friendlier environment and where the prospects of/for economic development are stronger. Such cities are to be considered as the sum of the various improvements in urban infrastructure, the quality of services provided to citizens, the operational costs of public administration. Romania has several key cities that have begun their pivot from regular and only digitized cities, to smart cities. According to information from the Romanian Smart City Association (ARSC), in 2018, at Romanian national level, 24 cities could be considered smart, the following cities being most visible in terms of how many projects have been undertaken so as to develop a smart city: Alba lulia city has 60 such projects, Cluj-Napoca city has 10, Arad has 9, Sibiu and Oradea each have 8 projects, and Bucharest has started six such projects. At 2020 level, we notice an increase in the number of projects in the following way: Alba-lulia now has 106 projects, Cluj-Napoca has 54 projects, Timisoara 26, Arad and lasi have each 19 projects, Brasov and Bucuresti (Sector 4) have 18 projects each, Oradea 17, Sibiu 15, and Piatra Neamt 15 projects. The main areas of interest being Smart Mobility, Smart Governance, Smart Living, Smart Economy, Smart Environment, and Smart People. Having set goals of cutting energy costs by $30 \%$ in the field of public transportation and an increase of $45 \%$ in terms of innovation products that are to be sourced locally, the city of Oradea has attracted project worth 369 million euros, and this entire sum has been achieved through EU funded grants.
\end{abstract}

Keywords: urban development; smart; digitalization; public administration; Romania; Oradea.

JEL Classification: H83; O18; Q56; R11.

\section{Introduction}

The involvement of local government leaders is essential for the success of the process of transforming a city into a smart one. They must act so that the future smart city is not a city "surrendered" to and led by large technology companies, with just a little involvement from citizens who are controlled and isolated within the cities. Even if the pragmatic goal of a smart city is to improve the quality of urban life, that city must be a lively, sustainable, inclusive, and interesting place to live and work in, achieved through the civic involvement of its inhabitants. The municipality and the local leaders need to engage in extensive community mobilization, communicating to citizens not only the future benefits but also the costs (financial, organizational, comfort), profitability of projects, efficiency gains and temporary interruptions of services, technological benefits and the problems related to data 
security etc. Costs, expenditures, financing options, public-private partnerships are other areas that need to be well managed and brought to the attention of citizens, to take advantage of emerging technologies.

Any integrative initiative taken towards achieving the smart city status must consider the milestones achieved so far, the European blueprint with its recommendations, relevant proposals and strategic partnerships available, so that it can best consolidate the smart city venture. Therefore, in this paper, after briefly discussing the main perspectives on smart city and smart administration, we mentioned the commitment and the guidance offered by the European Union to reach the status of a smart city, then we aimed to build an image of the smart city within the experiences of Romania and zoomed in on the city of Oradea and its comprehensive smart city enterprise. The all-around evaluation of Oradea's route to smartness incorporated analyses of its strategies, the functional areas targeted, the projects incorporated by each functional area, the funding available for smart transformation and the implementation stages of current projects, all these for highlighting important and relevant recommendations for future smart administration.

\section{Smart city, smart administration. A brief literature review}

Although research on the topic of smart cities tends to be relatively new in nature, literature on the topic is rich, diverse, and ever so growing.

Meijer and Rodriguez Bolivar (2016) notice a difference between Richard Florida's views about the global (external) competition of creative cities (Florida, 2002), and the vision of the competition for the improvement of life inside cities, promoted by Charles Landry (Landry, 2006). According to Lee et al. (2014) a smart city is a creative and sustainable area that improves the quality of life, a friendlier environment and where the prospects of/for economic development are stronger (Lee et al., 2014). When referring to a city as being "smart", we must take it as representing the sum of the various improvements in urban infrastructure, the quality of services provided to citizens, the operational costs of public administration (Zanella et al., 2014), or, to regard it as an interaction of "functional areas" such as Smart Mobility, Smart Living, Smart Governance, Smart Economy, Smart Environment, Smart People (Caragliu et al., 2011; Winkowska et al., 2019).

For Arroub et al. (2016) a smart city is in a likelihood a reality we are heading towards, but more importantly, it is a promising vision of the future, in which cities will progress to improve the wellbeing of both citizens and companies, by offering secure, affordable and sustainable spaces. However, the authors do point out that that achieving these goals and initiatives involves the contribution of all parts of the city. Policy and strategy makers, stakeholders, companies, the community and citizens need to work together with more transparency. The reasons for this are that Smart City initiatives are based on the intensive and comprehensive use of technologies, research, academia, professionals in/from various fields, are at the forefront of these transformations and have an extraordinary task, marked by technical and technological challenges. "Several ICT fields like loT, Al, big data analysis, nano-technology are involved are involved in the process of creating more Smart City scenarios" (Arroub et al., 2016).

Part of literature concerning the notion and concept of smart city has exhaustively approached technical elements whereas others have mixed and combined technical elements and those pertaining to social or educational elements (Caragliu et al., 2011; Giffinger et al., 2007; Barletta et al., 2020; Falconer and Mitchell, 2012).

Although at times if is difficult to understand (due to sophisticated explanations, unclear boundary between possible and anticipatory), socio-technical analyzes prove their importance for "the enhancing of our theoretical understanding of the (contextual and 
specific) interactions between social/governmental structures and new technologies" (Meijer and Rodriguez Bolivar, 2016, p. 403).

Literature has seen numerous and intense debates as regards how best to govern smart cities (Keta, 2015; Veselitskaya et al., 2019; Badulescu and Badulescu, 2008), some contributions placing more importance upon smart governance, a modern adaptation of governance to smart city administration, while others see the governance of smart cities as a combination of innovative decision-making and management, or innovative forms of collaboration in public administration (Meijer and Rodriguez Bolivar, 2016; European Commission, 2020; Barletta et al., 2020).

The implementation and development of a smart city seems to have immense and stimulating advantages and facilities. However, the creation from scratch or the transformation of existing cities into "smart" ones is continuously marked by barriers and difficulties, dangers and errors (European Economic and Social Committee (EESC), 2015; Falconer and Mitchell, 2012; McGuire, 2018; Sterling, 2018; Veselitskaya et al., 2019; Winkowska et al., 2019; Badulescu et al., 2014; Trip and Badulescu, 2020):

- $\quad$ excessive focus on investments aimed at the use of advanced technologies without understanding the social problems, inequalities and latent conflicts of the citizens who actually live in these cities;

- $\quad$ neglecting the involvement of local communities in the configuration of technical solutions, limited awareness as regards specific current and future needs;

- $\quad$ the loss of the existing culture and of the unique, traditional charm, appreciated not only by tourists but also by locals, as an element of cohesion and pride;

- $\quad$ increasing local taxes and fees to finance investments in infrastructure, modern technologies, etc.,

Insufficient education for the widespread use of these facilities, cyber risks, etc.

The fact that today's big cities are complex, extremely diverse and increasingly difficult to approach, coped with the fact that such cities are full of uncertainties (Fernandez-Guell et al., 2016) is one of the biggest obstacles in defining a conceptual model and in the development of comprehensive technical solutions for implementing a smart city. The use of "smart" technological solutions when attempting to build smart cities from scratch have often been deemed as failures, which tend to be avoided and which are unattractive for voluntary relocations, precisely because they ignored many other aspects of everyday life (Winkowska et al., 2019; McGuire, 2018; Mock, 2016) focusing on advanced solutions, but often neglecting flexibility and humanity.

Despite of these challenges, steps have been made towards the rounding of this concept which to offer a basis for the smart cities' enactment. Consequently, the European Union vision for a smart city is ultimately disseminated through a series of roadmaps offering guidance for integrated planning and implementation of smart city projects and for fasttracking such projects that are also financially viable, in an integrated and inclusive way (see for example Smart City Guidance Package - SCGP and Climate-neutral \& Smart City Guidance Package).

\section{A thumbnail view of Romania}

As was previously mentioned, the European Commission defines a smart city as being "a place where traditional networks and services are made more efficient with the use of digital and telecommunication technologies for the benefit of its inhabitants and business" (European Commission, 2018). Given the constant development of the European Union (through the process of enlargement, economic development, technological development etc.) we can also notice the consistent advancement and transformation of European cities, development that targets each aspect of day-to-day activity, be it individual/group activity, 
or company-specific. Although the speed at which cities develop, become more innovative and "smart" varies from region to region, throughout the following chapter we aim to target and address country specific issues as regards this "smart city" development at Romanian level.

Even though developments in the direction of cities becoming "smart" are to be considered as newer in their refinement as opposed to other countries throughout Europe, Romania has, nonetheless, several key cities that have begun their pivot from regular and only digitized cities, to smart cities.

It might seem obvious that most information concerning the development trials and opportunities aimed at increasing the general well-being of a region/city would come from the capital city, yet, in the case of Romania, cities from various other regions have higher transparency levels. IMD World Competitiveness Index has tasked itself with creating and developing a Smart City Index. In the case of Bucharest, the capital city of Romania, we find that it occupies the 85th position in the rank, in terms of how developed it is from a smart city perspective. This ranking has been made on a sample of cities from 102 countries. The city has a low score for a range of activities/issues, from health and safety to mobility, to public and corporate governance (IMD World Competitiveness Index, 2019). The same study has shown that the main area for concern as regards the governing of the city refers to the issues of corruption $(67.2 \%$ of the respondents consider this as being the main area of concern for Bucharest), followed by road congestion, air pollution, and green spaces. Even if data are only available up until the year 2019, in future years an in-depth analysis will be made possible by using information from the Smart City Index. What is more, this index points to the direction towards which the attention of local authorities should be aimed at, in order to further develop Bucharest as a smart city. Therefore, in order to increase its ranking in terms of "smart city" features, local governing authorities should increase transparency as regards the decision-making process, the budgeting and the public spending, as well as increase awareness and collaborative participation. Even so, various positive steps have been taken in this direction, and we have noticed a broader involvement of the private sector in the activity of the public authorities. The city of Bucharest has made a partnership with the consulting branch of accounting giant Deloitte for the development of a draft strategy for the turning of Bucharest into a smart city (Romanian Insider, 2018).

Throughout Romania, we have found various organizations, both from the public and private sectors, that concern themselves with the task of nurturing and developing cities from the point of view of the present study. Even though their efforts are admirable, a certain unified or common policy approach should be developed, in order for the transition from digitized to smart cities to occur at a faster rate; a dual approach to the process of communication between the local/national authorities the private sector is a must.

According to information from the Romanian Smart City Association (ARSC), in 2018, at Romanian national level, 24 cities could be considered smart cities. The following cities are the most visible in terms of how many projects have been undertaken so as to develop a smart city: Alba lulia city has 60 such projects, Cluj-Napoca city has 10, Arad has 9, Sibiu and Oradea each has eight projects, and Bucharest has started six such projects (ARSC, 2019). A particular evolution can be noticed. In 2019, at Romania level, 331 projects aimed at developing cities from a "smart" perspective had been started, throughout 45 Romanian cities, while a mid-year 2020 report recorded a total of 594 projects in 87 cities. At 2020 level, we notice an increase in the number of projects in the following way: Alba-lulia now has 106 projects, Cluj-Napoca has 54 projects, Timisoara 26, Arad and lasi have each 19 projects, Brasov and Bucuresti Sector 4 have 18 projects each, Oradea 17, Sibiu 15, and Piatra Neamt 15 projects, these being the most important and visible cities. The main areas of interest/focus, for each of the concerned cities, are Smart Mobility, Smart Governance, Smart Living, Smart Economy, Smart Environment, and Smart People (Vegacomp 
Consulting, 2020). Out of all the projects in these cities, it is important to note the number of projects deployed in the city of Oradea that are focused on a specific functional area: eight smart mobility projects, four smart living projects, three smart governance projects, one smart economy, and one smart environment project. Thus, projects focused on improving the city from a Smart Mobility and Smart Living perspective have a higher share of the total numbers of projects aimed at transforming the city into a smart one.

\section{Table 1: Functional Area and Number of (Smart) Projects at Romanian national level} in 2020

\begin{tabular}{|l|c|c|}
\hline Functional Area & Number of Projects & Percentage of Total \\
\hline Smart Mobility & 188 & $31.65 \%$ \\
\hline Smart Governance & 130 & $21.89 \%$ \\
\hline Smart Living & 121 & $20.37 \%$ \\
\hline Smart Economy & 84 & $14.14 \%$ \\
\hline Smart Environment & 42 & $7.07 \%$ \\
\hline Smart People & 29 & $4.88 \%$ \\
\hline \multicolumn{2}{|c|}{ Source: Vegacomp Consulting (2020) }
\end{tabular}

As can be noticed from the Table 1 above, the most important areas of interest for the better development of smart cities at Romanian national level are developments and projects started in the area of Smart Mobility, Smart Governance, and Smart Living. A more in-depth analysis reveals that at city level, Alba lulia and Cluj-Napoca have proposed the greatest number of Smart Mobility solutions/projects, Cluj-Napoca registering 20 such projects, and Alba lulia 17. Regardless of the functional area, looking more in detail to the data recorded, we see that most of the proposed and/or started projects are focused on the following: intelligent city public lighting solutions, smart and adaptive parking, e-bike sharing, virtual public servants (for tax- paying purposes), free access to Wi-Fi, Self Service IT Terminals, smart waste management and systems. In the following part of the paper, our focus shall be placed upon analyzing the city of Oradea, in the western part of Romania.

\section{Oradea Municipality for a Smart City - Case Study}

Oradea is a city located in the Western part of Romania and is the most important city of Bihor county. At the end of January 2020, Bihor had a total number of 178566 employed individuals and that the gross average income for Bihor (was of 4115 RON (Romanian National Institute of Statistics, 2020), (roughly 858 euro). The same report revealed that, in the entirety of Bihor county, at the end of January 2020 , the unemployment rate was $1.5 \%$ out of a total population of 616264 people (Romanian National Institute of Statistics, 2020). In terms of a strategy for turning Oradea into a smart city, ever since 2015, the municipality has set guidelines for accomplishing this. The main areas of interest for the development of the city, according to this strategy formulated by the municipality, are the following: Smart Governance, Smart Mobility, Smart Living, Smart Education, Smart Citizens, Smart Infrastructure, Smart Environment, Smart Business and Information Security (Municipality of Oradea, 2016), (Badulescu et al, 2015). One of the main purposes of transforming this city refers to increasing innovation. Therefore, the municipality has proposed an increase of $45 \%$ in terms of innovative products that are to be produced locally, and, at administrative levels, to automate $80 \%$ of existing administrative processes (ranging from paying taxes and obtaining inquires, to facilitate communication between the public administration and the general population of Oradea). As concern areas of interest, the municipality plans to reform public transport and associated services, so that the city and the citizens can obtain 
real-time transportation data throughout the city of Oradea coupled with a reduction of energy costs by $30 \%$ (Municipality of Oradea, 2016). The Figure 1 summarizes the most important four areas for the development of Oradea as a smart city.

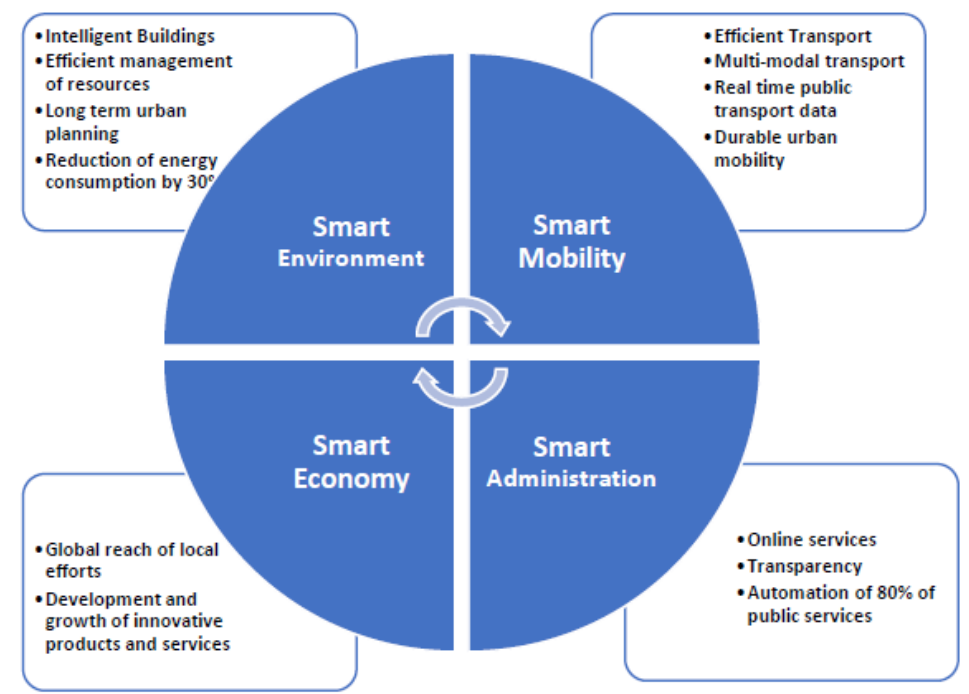

Figure 1: Main areas of focus for the development of Oradea as a smart city

Source: Adapted from the report of the Municipality of Oradea (Municipality of Oradea, 2016)

Even though some terms might be considered general, an activity/evaluation report by the same municipality sheds light on the specific ways in which Oradea has made essential steps into becoming a smart city. For each of the four major areas of focus for the municipality, specific projects have been started and are under development. In Figure 2 the specific projects that have been undertaken throughout each area of interest are highlighted:

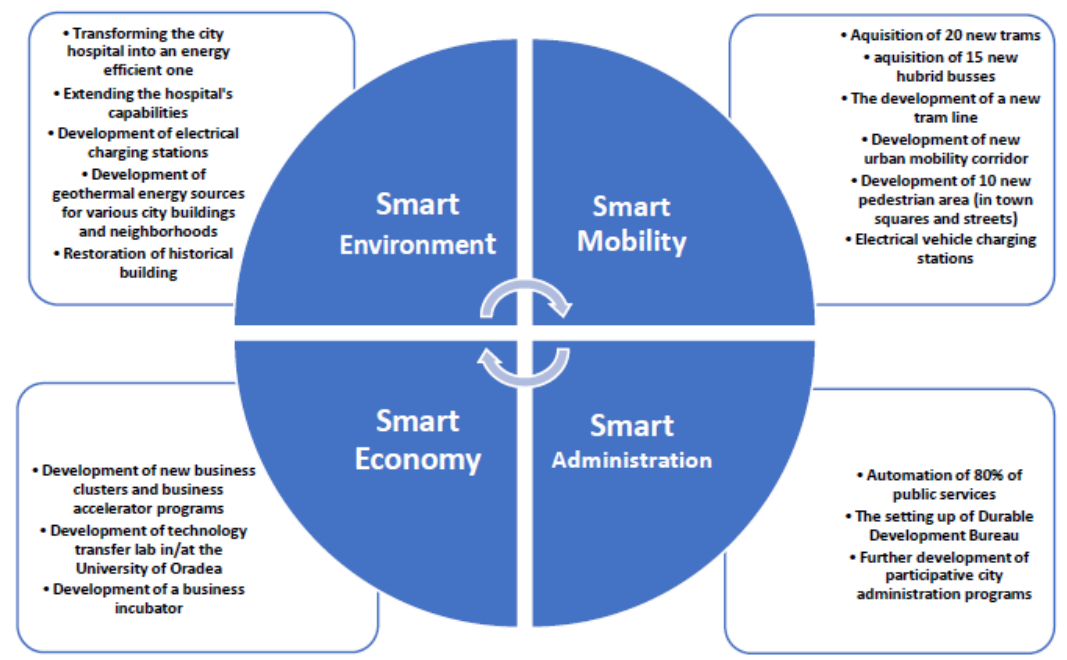

Figure 2: Specific projects for each of the 4 main areas of interest Source: Adapted from the 2019 municipality activity report (Project Management Directorate for International Financing, 2020) 
For the 2014-2020-time frame, Oradea has contracted and developed projects having a total value of 368.7 million euros, and this entire sum has been achieved through EU funded grants, from specific operational programs. There are still 81 investment grants that will be integrated into 59 projects. What is more, there are 41 projects that are yet being implemented, totaling approximately 209 million euros (Project Management Directorate for International Financing, 2020).

As has previously been mentioned, most projects implemented in Oradea have been funded through EU grants. Specifically, the distribution of operational programs through which grants have been funded are presented in Table 2.

Table 2. Funding programs and the relative share of value

\begin{tabular}{|l|c|c|}
\hline \multicolumn{1}{|c|}{ Funding Program } & $\begin{array}{c}\text { Accessed Grant } \\
\text { Amount (Euro) }\end{array}$ & $\begin{array}{c}\text { Percentage } \\
\text { of Total }\end{array}$ \\
\hline 2014-2020 Regional Operational Program & $233,188,589$ & 63.34 \\
\hline $\begin{array}{l}\text { 2014-2020 High Level Infrastructure } \\
\text { Operational Program }\end{array}$ & $105,865,404$ & 28.75 \\
\hline $\begin{array}{l}\text { 2014-2020 Cross-Border Romanian - } \\
\text { Hungarian Cooperation Program }\end{array}$ & $13,687,622$ & 3.72 \\
\hline Other grants & $15,436,005$ & 4.19 \\
\hline Total & $368,177,620$ & 100 \\
\hline
\end{tabular}

Source: Adapted from the municipality activity report (Project Management Directorate for International Financing, 2020)

The 41 projects that are still being implemented are in various areas of interest and have different development stages. Most of these projects regard rehabilitating various buildings throughout Oradea, for energetic efficiency (referring to both thermal and structural perspectives). Out of the 41 projects, 15 are concerned with the rehabilitation of buildings. Taken as a whole, the average development stage of these projects is $25 \%$, meaning that most of these projects are in their initial development stages. Separately, the development stage of the various rehabilitation projects is $18 \%$. Future research will be aimed at analyzing the impact that these 41 projects have had in transforming the city of Oradea into a noteworthy smart city.

\section{Conclusions and policy recommendations}

Our study presented an eagle-eye view of the Smart Cities of Romania, focusing in the second part on the city of Oradea, and bringing specific considerations on its drive towards implementing smart city initiatives. Having set goals of cutting energy costs by $30 \%$ in the field of public transportation and an increase of $45 \%$ in terms of innovation products that are to be produced locally, Oradea has set the bar high of what can be accomplished through strategic development. For the 2014-2020 time-period, Oradea has contracted and developed projects having a total value of 368.7 million euros, and this entire sum has been achieved through E.U. funded grants, from specific operational programs. There are still 81 investment grants that will be integrated in 59 projects. What is more, there are 41 projects that are still being implemented, totaling a value of 209 million euros. These projects are quite diverse in their nature and are focused on four functional areas for smart city development: smart environment, smart mobility, smart economy, and smart administration. The involvement of local government leaders is essential for the success of the process of transforming a city into a smart one. Whereas the pragmatic goal of a smart city is to improve the quality of urban life, that city must be a lively, sustainable, inclusive, and interesting 
place to live and work in, achieved through the civic involvement of its inhabitants. First of all, they need to engage in extensive community mobilization, communicating openly and honestly to citizens not only the future benefits but also the costs (financial, organizational, comfort), profitability of projects, efficiency gains and temporary interruptions of services, technological benefits and the problems related to data security, etc. City leaders must also ensure that as the city advances on the scale of technology and integration, lost jobs are offset by new opportunities, occasions for retraining and support for low-income areas are offered, so that citizens would find advantages in new services and the digital divide is reduced.

Costs, expenditures, financing options, public-private partnerships are other areas that need to be well managed and brought to the attention of citizens, as improving public services and converting existing municipal assets to new revenue sources are made for their residents' lives, to take advantage of emerging technologies.

Also, leaders need to be informed of changes in national legislation, opportunities to offer subsidies for these actions, tax responsibilities, data confidentiality, to ensure managed competition of municipal services and the motivation of public service employees.

As we have seen, given the speed at which transformation takes place, it proves vital for each and every city to strive to achieve the status of smart city as fast as possible. Although there are some disparities in terms of how many cities are smart (in comparison to the cities that still strive to obtain this title) and there are still some challenges left, the effort undertaken in this direction by Romania as a country and by the local government in this direction clearly points at numerous benefits that are still to come. Smart city governments and leaders will want to continue to be at the forefront of the smart city's evolutionary trajectory to ensure that residents' needs are met in the smartest, most efficient and most cost-effective manner.

\section{References}

1. Arroub, A., Zahi, B., Sabir, E. and Sadik, M. (2016) A Literature Review on Smart Cities: Paradigms, Opportunities and Open Problems, International Conference on Wireless Networks and Mobile Communications (WINCOM), pp. 180-186. DOI:10.1109/WINCOM.2016.7777211.

2. ARSC (Romanian Smart City Association) (2019) ARSCM - Raport de activitate 2018, [Online], Available: https://romaniansmartcity.ro/arsc-smart-city/ [24 Mar 2021].

3. Badulescu, A., Badulescu, D. and Borma, A. (2014) "Enhancing cross-border cooperation through local actors' involvement. The case of tourism cooperation in Bihor (Romania) - Hajdú-Bihar (Hungary) Euroregion", Lex Localis, Vol. 12, No. 3, pp. 349-371. DOI: 10.4335/12.3.349-371.

4. Badulescu, D.; Badulescu, A. and Bucur, C.-A. (2015) Considerations on the Effectiveness of CrossBorder Cooperation in Public Order and Civil Protection Services. The Case of the Romanian Hungarian Border Area, Lex Localis-Journal of Local Self-Government, Vol. 13, No.3, pp. 559-578. https://doi.org/10.4335/13.3.559-578(2015).

5Badulescu, D. and Badulescu, A. (2008) "Theoretical Background of Corporate Governance (I)", Annals of the Oradea University, Fascicle of Management and Technological Engineering, Vol. 7, No.17, pp. 1886-1990.

6. Barletta, V.S., Caivano, D., Dimauro, G., Nannavecchia, A. and Scalera, M. (2020) "Managing a Smart City Integrated Model through Smart Program Management", Applied Sciences, Vol. 10, No. 2, pp. 714. DOI: 10.3390/app10020714.

7. Caragliu, A., Del Bo, C. and Nijkamp, P. (2011) "Smart Cities in Europe", Journal of Urban Technology, Vol. 18, No. 2, pp. 65-82. DOI: 10.1080/10630732.2011.601117.

8. European Commission (2018) Smart cities, [Online] Available at: https://ec.europa.eu/info/euregional-and-urban-development/topics/cities-and-urban-development/city-initiatives/smart-cities en [02 Febr 2020].

9. European Commission (2020) Smart Cities - Smart Living, [Online] Available at: https://ec.europa.eu/digital-single-market/en/smart-cities-smart-living [22 Mar 2021].

10. European Economic and Social Committee (EESC) (2015) Smart cities as a driver of a new European industrial policy, Official Journal of the European Union, Vol. 58, Brussels. 
11. Falconer, G. and Mitchell, S. (2012) Smart City Framework. A Systematic Process for Enabling Smart+Connected Communities, [Online] Available at: https://www.cisco.com/c/dam/en us/about/ac79/docs/ps/motm/Smart-City-Framework.pdf [17 Febr 2020].

12. Fernandez-Guell, J., Guzman-Arana, S., Collado-Lara, M. and Fernandez-Anez, V. (2016) "How to Incorporate Urban Complexity, Diversity and Intelligence into Smart Cities Initiatives", Smart-CT 2016: Proceedings of the First International Conference on Smart Cities, Vol. 9704, pp. 85-94. DOI: 10.1007/978-3-319-39595-1_9.

13. Florida, R. (2002) The Rise of the Creative Class: And How it's Transforming Work, Leisure, Community and Everyday Life, Basic Books, New York.

14. Giffinger, R., Fertner, C., Kramar, H., Meijers, E. and Pichler-Milanovic, N. (2007) "City-ranking of European medium-sized cities", Centre of Regional Science, Vienna University of Technology, pp. 112.

15. IMD World Competitiveness Index (2019) Smart City Index, [Online] Available at: https://www.imd.org/research-knowledge/reports/imd-smart-city-index-2019/ [20 Mar 2020].

16. Keta, M. (2015) "Smart City, Smart Administration and Sustainible Development", Romanian Economic and Business Review, Vol. 10, No. 3, pp. 43-56.

17. Landry, C. (2006) The Art of City Making, Routledge, London.

18. Lee, J., Hancock, M. and Hu, M.C. (2014) "Towards an effective framework for building smart cities: Lessons from Seoul and San Francisco", Technological Forecasting and Social Change, Vol. 89, pp. 80-99. DOI: 10.1016/j.techfore.2013.08.033.

19. McGuire, M. (2018) "Beyond flatland: when smart cities make stupid citizens", City, Territory and Architecture, Vol. 5, No. 22. DOI: 10.1186/s40410-018-0098-0.

20. Meijer, A. and Rodriguez Bolivar, M. (2016) "Governing the smart city: a review of the literature on smart urban governance", International Review of Administrative Sciences, Vol. 82, No. 2, pp. 392408. DOI: $10.1177 / 0020852314564308$.

21. Mock, J. (2016) "Smart City—Stupid Countryside", In: Mock, J., Kawamura, H. and Naganuma, N. (eds.), The Impact of Internationalization on Japanese Higher Education. Global Perspectives on Higher Education, Vol. 22, pp. 191-296, SensePublishers, Rotterdam. DOI: 10.1007/978-94-6300-1694_12.

22. Municipality of Oradea (2016) Integrated strategy for digitaizing the Municipality of Oradea (Strategia integrata de informatizare a Municipiului Oradea), [Online] Available at: http://www.oradea.ro/stiri-oradea/primaria-oradea-inten-539-ioneaza-sa-elaboreze-o-strategie-

integrata-de-informatizare-a-municipiului [17 Mar 2020].

23. Project Management Directorate for International Financing (2020) Annual Activity Report 2019, [Online] Available

https://op.europa.eu/documents/10530/1406391/Annual+Activity+Report+2019.pdf/ [24 Mar 2020].

24. Romanian Insider (2018) Bucharest City Hall selects consultant for Smart City strategy, [Online] Available at: https://www.romania-insider.com/bucharest-consultant-smart-city [17 Mar 2020].

25. Romanian National Institute of Statistics (2020) Balanța forței de muncă la 1 ianuarie 2020, [Online] Available

at:

https://insse.ro/cms/sites/default/files/field/publicatii/balanta fortei de munca la 1 ianuarie 2020.p df [24 lul 2020].

26. Sterling, B. (2018) Stop Saying 'Smart Cities'. Digital stardust won't magically make future cities more affordable or resilient, [Online] Available at: https://www.theatlantic.com/technology/archive/2018/02/stupid-cities/553052/, [Accessed 12 Mar 2020].

27. Trip, D. and Badulescu, D. (2020) Touchless Tourism - How new tourism will look like, Oradea, 11th Edition of Griffiths School of Management and IT Annual Conference - GSMAC 2020.

28. Vegacomp Consulting (2020) Radiografia Smart City în România - Accelerarea digitalizarii oraselor, dupa pandemie, [Online] Available at: https://vegacomp.ro/wpr/wpcontent/uploads/2020/06/raport-radiografie-smart-city-romania-iunie-2020 final-1.pdf [Accessed 07 Apr 2021].

29. Veselitskaya, N., Karasev, O. and Beloshitskiy, A. (2019) "Drivers and Barriers for Smart Cities Development", Theoretical and Empirical Researches in Urban Management, Vol. 14, No. 1, pp. 85110. 
The Annals of the University of Oradea. Economic Sciences

TOM XXX, $1^{\text {st }}$ Issue, July 2021

30. Winkowska, J., Szpilko, D. and Pejić, S. (2019) "Smart city concept in the light of the literature review", Engineering Management in Production and Services, Vol. 11, No. 2, pp. 70-86. DOI: 10.2478/emj-2019-0012.

31. Zanella, A., Bui, N., Castellani, A., Vangelista, L. (2012) "Internet of things for smart cities", IEEE Internet of Things Journal, Vol. 1, No. 1, pp. 22-32. DOI: 10.1109/JIOT.2014.2306328. 